\title{
Monitoring active volcanoes: The geochemical approach
}

\author{
Salvatore Inguaggiato ${ }^{1,{ }^{\star}}$, Agnes Mazot $^{2}$, Takeshi Ohba $^{3}$ \\ ${ }^{1}$ Istituto Nazionale di Geofisica e Vulcanologia, sezione di Palermo, Palermo, Italy \\ ${ }^{2}$ GNS Science, Wairakei Research Centre, Department of Volcanology, Taupo, New Zealand \\ ${ }^{3}$ Tokai University, School of Science, Department of Chemistry, Kanagawa, Japan
}

Volcanic systems: Shallow magmas located beneath active volcanoes release volatiles both during eruptive activity and during inter-eruptive periods (passive degassing). The fluids in active volcanic areas rise directly from magma, and their composition is characterized mainly by $\mathrm{H}_{2} \mathrm{O}, \mathrm{CO}_{2}, \mathrm{SO}_{2}, \mathrm{H}_{2} \mathrm{~S}, \mathrm{HF}$ and $\mathrm{HCl}$ (condensable gases), and by some non-condensable gases (e.g. $\mathrm{He}, \mathrm{H}_{2}, \mathrm{~N}_{2}, \mathrm{CO}, \mathrm{CH}_{4}$ ).

The chemical composition of fumarolic gases can reflect the pressure, temperature and oxygen fugacity conditions of the deep magmatic source, provided that during their rise towards the surface, the gases do not undergo re-equilibration processes [Giggenbach 1980, Giggenbach 1996, Nuccio and Paonita 2001, Paonita et al. 2002]. As the equilibrium kinetics of several chemical reactions is much slower than the rising velocities of the gases, the gas molecular compositions often undergo quenching phenomena, so that the gases show temperature and pressure equilibria higher than their outlet values.

The concentration of magmatic species or their molecular ratios can be determined by means of direct sampling of fumarole gases or by using telemetric methods of observation. The extensive parameters (mass output) of volcanic fluids, coupled with the intensive parameters described before, provide basic and useful information for the formulation of volcanic fluid degassing models [Italiano et al. 1997, Brusca et al. 2004, Inguaggiato et al. 2011].

The first step in the framework of the geochemical investigation of a volcanic system aimed at surveillance is the chemical and isotopic characterization of the fluids, and the putting forward of a geochemical model [Inguaggiato et al. 2011]; within this geochemical model, it is possible to interpret the observed changes in any single investigated parameter. The geochemical approach is to identify the following topics:

- The main end-members involved in the studied system;

- The possible type and degree of interaction processes: e.g. water-rock and gas-water interactions;

- The mixing among the individual end-members;

- The chemical and isotopic characterization of a possible hydrothermal system;

- The formulation of a geochemical model.

The geochemical surveillance of an active volcano aims to recognize possible signals that are related to changes in volcanic activity. Indeed, as a consequence of the magma rising inside the volcanic "plumbing system" and/or the refilling with new batches of magma, the dissolved volatiles in the magma are progressively released as a function of their relative solubilities. When approaching the surface, these fluids that are discharged during magma degassing can interact with shallow aquifers and/or can be released along the main volcano-tectonic structures. Under these conditions, the following main degassing processes represent strategic sites to be monitored:

1) Fumaroles [Gerlach and Nordlie 1975, Giggenbach 1980, Taran et al. 1986, Gerlach 1993, Giggenbach 1996, Capasso et al. 1997, Giammanco et al. 1998, Nuccio and Paonita 2001, Paonita et al. 2002, Liotta et al. 2010];

2) Diffused soil degassing [Chiodini et al. 1996, Chiodini et al. 1998, Favara et al. 2001, 
Diliberto et al. 2002, Cardellini et al. 2003, Brusca et al. 2004, Chiodini et al. 2005, Pecoraino et al. 2005, Werner and Cardellini 2006, Inguaggiato et al. 2011, Mazot et al. 2011];

3) Degassing associated with geothermal waters [Capasso and Inguaggiato 1998, Taran et al. 1998, Inguaggiato et al. 2000, Inguaggiato and Rizzo 2004, Inguaggiato et al. 2004, Inguaggiato et al. 2005, Liotta et al. 2006, Rouwet et al. 2008, Inguaggiato et al. 2010, Inguaggiato et al. 2011];

4) Plumes [Oppenheimer et al. 1998, Bruno et al. 1999, Galle et al. 2003, Aiuppa et al. 2004, Aiuppa et al. 2005, McGonigle 2005, Burton et al. 2007a, Burton et al. 2007b, Aiuppa et al. 2009].

The main purpose of this special volume is to collect papers that cover a wide range of topics in volcanic fluid geochemistry, which include geochemical characterization and geochemical monitoring of active volcanoes using different techniques and at different sites. Moreover, part of this volume has been dedicated to the new geochemistry tools. In particular:

Tassi et al. show a classic approach to characterize a volcanic system (Chilean volcanoes) based on the chemistry and isotope composition of fumaroles, discussing the mantle, slab and atmospheric contributions to volcanic emissions;

Caliro et al. report on a long time-series of chemical and isotopic compositions of Vesuvius fumaroles that were acquired in the framework of a volcanic surveillance period (1998-2010), and that allow the identification of processes that occur at shallow levels in the hydrothermal systems, and the variations induced by deep changes in volcanic activity;

Chiodini et al. report on a long time-series of fluid pressure and temperature within the hydrothermal system feeding the Solfatara fumaroles, investigated here on the basis of chemical equilibria within the $\mathrm{CO}_{2}-\mathrm{H}_{2} \mathrm{O}-\mathrm{H}_{2}-\mathrm{CO}$ gas system;

Rouwet and Tassi present a study of a generalized box model approach that can be useful for geochemical monitoring of active crater lakes, as highly dynamic natural systems. The mass budget of a lake is based on observations of physical variations over a certain period of time: lake volume (level, surface area), lake water temperature, meteorological precipitation, air humidity, wind velocity, input of spring water, and overflow from the lake;

Diliberto presents temperature data acquired from 1998 to 2010 by continuous monitoring of fumaroles, and discusses the time relationships of the different parameters related to the activity of the volcanic system. During the study period, temperature and compositional changes in the fumarolic gases took place at the same time as variations in a number of volcanoseismic events, indicating frequent variations of energy release (heat and mass flow, as well as seismic strain release).

Geochemical modeling applied to the volcanic system of Vulcano suggests that the overall expansion of magmatic gas through the fractured system is an almost iso-enthalpic process at depth, which shifts to an adiabatic process at shallow depths, where the rock permeability increases. This interpretation encourages fumarole temperature monitoring and suggests that only a multidisciplinary approach that considers the geochemical and geophysical parameters should be considered to explain the recorded variations.

Ohba et al. indicate that in 1998, many volcanic earthquakes were observed at Iwate volcano, Japan. However, although an eruption was anticipated, it never occurred. Fumarolic gases were sampled at the volcano on six occasions during 1998 and 1999, and were analyzed for their chemical compositions and isotope ratios. Fumarolic gases were again sampled in 2004 and 2006, after the period of seismic activity. The $\mathrm{HCl}$ concentrations and isotope ratios of $\mathrm{H}_{2} \mathrm{O}$ in the gas samples collected from an active geothermal area of the volcano were high in 1998 and 1999, but decreased significantly after 2004, irrespective of the relatively stable 
concentrations of $\mathrm{CO}_{2}$ and sulfur-bearing gases. A notable feature of the fumarolic gases is the high isotope ratio of $\mathrm{H}_{2} \mathrm{O}$, which is similar to that of the pure magmatic gas that is typical of andesitic volcanoes, although the temperature at the outlet was less than $146^{\circ} \mathrm{C}$ in the present case. The above features can be explained if the enthalpy of the magmatic gas was equivalent to that of water vapor at $252{ }^{\circ} \mathrm{C}$ to $370{ }^{\circ} \mathrm{C}$ under a pressure of 1 bar. The correlations observed among $\mathrm{CO}_{2} / \mathrm{H}_{2} \mathrm{O}, \mathrm{HCl} / \mathrm{H}_{2} \mathrm{O}$, and $\delta^{18} \mathrm{O}$ values of the fumarolic gases suggest the partial condensation of $\mathrm{H}_{2} \mathrm{O}$ vapor during the ascent of the volcanic gas to the surface. The estimated $\mathrm{CO}_{2} / \mathrm{H}_{2} \mathrm{O}$ molar ratio of the magmatic gas is 0.008 , which is less than the value of 0.03 reported previously for magmatic gas sampled during an effusive eruption at Unzen volcano, Japan.

Tamburello et al. indicate that measurements of volcanic $\mathrm{SO}_{2}$ emission rates have been the mainstay of remotely sensed volcanic gas geochemistry for almost four decades, with significant contributions to our understanding of volcanic systems and their impact upon the atmosphere. The last ten years have brought step-change improvements to the instrumentation applied to these observations, beginning with the application of miniature ultraviolet spectrometers deployed in scanning and traverse configurations, with DOAS evaluation routines. This study catalogues the more recent empirical developments, such as: ultraviolet cameras; wide angle field-of-view DOAS systems; advances in scanning operations, including tomography; and improved understanding of errors, in particular concerning radiative transfer. Furthermore, the outcomes of the field deployment of these sensors over the last decade are documented, with respect to improving our understanding of volcanic dynamics and degassing to the atmosphere.

The last part of this special volume collects articles together that describe new instrumentation and tools to monitoring active volcanoes. In particular:

Inguaggiato et al. show new home-made equipment designed to measure the continuous partial pressure of $\mathrm{CO}_{2}$ in the natural waters, along with its application to the thermal aquifer of Stromboli Island;

and finally:

Tamburello et al. report on a new tool to measure and analyze the $\mathrm{SO}_{2}$ flux of the volcanic plume using an $\mathrm{SO}_{2}$ camera. This study describes Vulcamera, a stand-alone program for the determination of volcanic $\mathrm{SO}_{2}$ fluxes using ultraviolet cameras. The code enables field image acquisition, and provides all of the required post-processing operations.

\section{References}

Aiuppa, A., M. Burton, F. Muré and S. Inguaggiato (2004). Intercomparison of volcanic gas monitoring methodologies performed on Vulcano Island, Italy, Geophys. Res. Lett., 31, L02610; doi: $10.1029 / 2003$ GL018651.

Aiuppa, A., S. Inguaggiato, A.J.S. McGonigle, M. O'Dwyer, C. Oppenheimer, M.J. Padgett, D. Rouwet and M. Valenza (2005). $\mathrm{H}_{2} \mathrm{~S}$ fluxes from Mt. Etna, Stromboli and Vulcano (Italy) and implications for the sulfur budget at volcanoes, Geochim. Cosmochim. Acta, 69, 1861-1871.

Aiuppa, A., C. Federico, G. Giudice, G. Giuffrida, R. Guida, S. Gurrieri, M. Liuzzo, M. Moretti and P. Papale (2009). The 2007 eruption of Stromboli volcano: insights from real-time measurement of the volcanic gas plume $\mathrm{CO}_{2} / \mathrm{SO}_{2}$ ratio, J. Volcanol. Geotherm. Res., 182, 221-230.

Bruno, N., T. Caltabiano, and R. Romano (1999). $\mathrm{SO}_{2}$ emissions at Mt. Etna with particular reference to the period 1993-1995, Bull. Volcanol., 60, 405-411.

Brusca, L., S. Inguaggiato, M. Longo, P. Madonia and R. Maugeri (2004). The 2002-2003 eruption of Stromboli (Italy): evaluation of the volcanic activity by means of continuous monitoring of soil temperature, $\mathrm{CO}_{2}$ flux, and meteorological parameters, Geochem. Geophys. Geosyst., 5, Q12001; doi: 10.1029/2004GC000732.

Burton, M., P. Allard, A. La Spina and F. Muré (2007a). Magmatic gas composition reveals the 
source depth of slug-driven Strombolian explosive activity, Science; doi: 10.1126/science. 1141900.

Burton, M.R., H.M. Mader and M. Polacci (2007b). The role of gas percolation in quiescent degassing of persistently active basaltic volcanoes, Earth Planet Sci. Lett., 264, 46-59.

Capasso, G., Favara R. and S. Inguaggiato (1997) Chemical features and isotopic composition of gaseous manifestations on Vulcano Island (Aeolian Islands, Italy): an interpretative model of fluid circulation, Geochim. Cosmochim. Acta, 61, 3425-3440.

Capasso, G. and S. Inguaggiato (1998). A simple method for the determination of dissolved gases in natural waters: An application to thermal waters from Vulcano island, Appl. Geochem., 13, 631-642.

Cardellini, C., G. Chiodini and F. Frondini (2003). Application of stochastic simulation to $\mathrm{CO}_{2}$ flux from soil: Mapping and quantification of gas release, J. Geophys. Res., 108 (B9), ECV3.1ECV3.13; doi: 10.1029/2002JB002165.

Chiodini, G., F. Frondini and B. Raco (1996). Diffuse emission of $\mathrm{CO}_{2}$ from the Fossa crater, Vulcano Island (Italy), Bull. Volcanol., 58, 41-50.

Chiodini, G., R. Cioni, M. Guidi, B. Raco and L. Marini (1998). Soil $\mathrm{CO}_{2}$ flux measurements in volcanic and geothermal areas, Appl. Geochem., 13, 543-552.

Chiodini, G., D. Granieri, R. Avino, S. Caliro, A. Costa and C. Werner (2005). Carbon dioxide diffuse degassing and estimation of heat release from volcanic and hydrothermal systems, J. Geophys. Res., 110, B08204; doi: 10.1029/2004JB003542.

Diliberto, I.S., S. Gurrieri and M. Valenza (2002). Relationships between diffuse $\mathrm{CO}_{2}$ emissions and volcanic activity on the island of Vulcano (Aeolian Islands, Italy) during the period 19841994, Bull. Volcanol., 64, 219-228.

Favara, R., S. Giammanco, S. Inguaggiato and G. Pecoraino (2001). Preliminary estimate of $\mathrm{CO}_{2}$ output from Pantelleria Island volcano (Sicily, Italy): evidence of active mantle degassing, Appl. Geochem., 16, 883-894.

Galle, B., C. Oppenheimer, A. Geyer, A.J.S. McGonigle, M. Edmonds and L.A. Horrocks (2003). A miniaturised ultraviolet spectrometer for remote sensing of $\mathrm{SO}_{2}$ fluxes: A new tool for volcano surveillance, J. Volcanol. Geotherm. Res., 119, 241-254.

Gerlach, T.M. and B.E. Nordlie (1975). The C-O-H-S gaseous systems. Part II: temperature, atomic composition, and molecular equilibria in volcanic gases, Am. J. Sci., 275, 377-394.

Gerlach, T.M. (1993). Oxygen buffering of Kilauea volcanic gases and the oxygen fugacity of Kilauea basalt, Geochim. Cosmochim. Acta, 57, 795-814.

Giammanco, S., S. Inguaggiato and M. Valenza (1998). Soil and fumarole gases of Mount Etna: geochemistry and relations with volcanic activity, J. Volcanol. Geotherm. Res., 81, 297-310.

Giggenbach, W.F. (1980). Geothermal gas equilibria, Geochim. Cosmochim. Acta, 44, 20212032.

Giggenbach, W.F. (1996). Chemical composition of volcanic gases, In: R. Scarpa and R. Tilling (eds), Monitoring and Mitigation of Volcano Hazards, Springer-Verlag, Berlin, 221-256.

Inguaggiato, S., G. Pecoraino and F. D'Amore (2000). Chemical and isotopical characterization of fluid manifestations of Ischia Island (Italy), J. Volcanol. Geotherm. Res., 99, 151-178.

Inguaggiato, S. and A. Rizzo (2004). Dissolved helium isotope ratios in ground-waters: a new technique based on gas-water re-equilibration and its application to Stromboli volcanic system, Appl. Geochem., 19, 665-673.

Inguaggiato, S., Y.A. Taran, F. Grassa, G. Capasso, R. Favara, N. Varley and E. Faber (2004). Nitrogen isotopes in thermal fluids of a forearc region (Jalisco Block, Mexico): evidence for heavy nitrogen from continental crust, Geochem. Geophys. Geosyst., 5, Q12003; doi: 10.1029/2004GC000767.

Inguaggiato, S., A.L. Martin-Del Pozzo, A. Aguayo, G. Capasso and R. Favara (2005). Isotopic, chemical and dissolved gas constraints on spring water from Popocatépetl (Mexico): evidence of gas-water interaction magmatic component and shallow fluids, J. Volcanol. Geotherm. Res., 141, 91-108.

Inguaggiato, S, S. Hidalgo, B. Beate and J. Bourquin (2010). Geochemical and isotopic character- 
ization of volcanic and geothermal fluids discharged from the Ecuadorian volcanic arc, Geofluids, 10, 525-541.

Inguaggiato, S., F. Vita, D. Rouwet, N. Bobrowski, S. Morici and A. Sollami (2011). Geochemical evidence of the renewal of volcanic activity inferred from $\mathrm{CO}_{2}$ soil and $\mathrm{SO}_{2}$ plume fluxes: the 2007 Stromboli eruption (Italy), Bull. Volcanol., 73 (4), 443-456.

Italiano, F., G. Pecoraino and P.M. Nuccio (1997). Steam output from fumaroles of an active volcano: Tectonic and magmatic-hydrothermal controls on the degassing system at Vulcano (Aeolian arc), J. Geophys. Res., 103, 29829-29842.

Liotta, M., L. Brusca, F. Grassa, S. Inguaggiato, M. Longo and P. Madonia (2006). Geochemistry of rainfall at Stromboli volcano (Aeolian Islands): Isotopic composition and plume-rain interaction, Geochem. Geophys. Geosyst., 7, Q07006; doi: 10.1029/2006GC001288.

Liotta, M., A. Paonita, A. Caracausi, M. Martelli, A. Rizzo and R. Favara (2010). Hydrothermal processes governing the geochemistry of the crater fumaroles Mount Etna volcano (Italy), Chem. Geol., 278, 92-104.

Mazot, A., D. Rouwet, Y. Taran, S. Inguaggiato and N. Varley (2011). $\mathrm{CO}_{2}$ and He degassing at El Chichón volcano (Chiapas, Mexico): gas flux, origin, and relationship with local and regional tectonics, Bull. Volcanol., 73 (4), 423-441; doi: 10.1007/s00445-010-0443-y.

McGonigle, A.J.S. (2005). Volcano remote sensing with ground-based spectroscopy, Phil. Trans. R. Soc. A, 363, 2915-2929; doi: 10.1098/rsta.2005.1668.

Nuccio, P.M. and A. Paonita (2001). Magmatic degassing of multicomponent vapors and assessment of magma depth: application to Vulcano Island (Italy), Earth Planet Sci. Lett., 193, 467-481.

Oppenheimer, C., P. Francis, M. Burton, A.J.H. Maciejewski and L. Boardman (1998). Remote measurement of volcanic gases by Fourier transform infrared spectroscopy, Appl. Phys., 67, 505-515.

Paonita, A., R. Favara, P.M. Nuccio and F. Sortino (2002). Genesis of fumarolic emissions as inferred by isotope mass balances: $\mathrm{CO}_{2}$ and water at Vulcano Island, Italy, Geochim. Cosmochim. Acta, 66, 759-772.

Pecoraino, G., L. Brusca, W. D'Alessandro, S. Giammanco, S. Inguaggiato and M. Longo (2005). Total $\mathrm{CO}_{2}$ output from Ischia Island volcano (Italy), Geochem. J., 39, 451-458.

Rouwet, D., S. Inguaggiato, Y. Taran, N. Varley and J.A. Santiago (2008). Chemical and isotopic compositions of thermal springs, fumaroles and bubbling gases at Tacaná Volcano (MexicoGuatemala): implications for volcanic surveillance, Bull. Volcanol., 59, 436-449.

Taran, Y.A., A.D. Esikov and A.L. Cheshko (1986). Deuterium and Oxygen-18 in waters of Mutnovsky geothermal area, Geochem. Int., 4, 458-468.

Taran, Y., T.P. Fisher, B. Pokrovsky, Y. Sano, M. Armienta and J.L. Macias (1998). Geochemistry of the volcano-hydrothermal system of El Chichón Volcano, Chiapas, Mexico, Bull. Volcanol., 59, 436-449.

Werner, C. and C. Cardellini (2006). Comparison of carbon dioxide emissions with fluid upflow, chemistry, and geologic structures at the Rotorua geothermal system, New Zealand, Geothermics, 35, 221-238. 